\title{
シクロオクタテトラェン
}

吉田 政 幸*

\author{
Cyclooctatetraene.
}

Masayuki YoshidA*

今世紀の始めに，ベンゼンより二重結合を一つ多くも つ 1, 3, 5,7-シクロオク タテトラエン (COT) がベンゼ ンと同じような性質をもっているかどうか化学者の間で 問題になっていた。1913 年, Willstätter は擬ペレチレ ン (1) (pseudopelletierene) より出発し, 次々に二重結 合を導入して COT の合成に成功した ${ }^{2)}$ 。すなわち，(1)

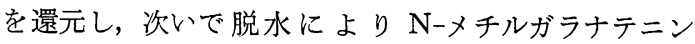
(3) とし, 徹底的メチル化 (exhaustive methylation) で N, N-ジメチルアミノ-2,4-シクロオクタジェン (4) とした。（4）を徹底的メチル化でシクロオクタトリエン (5)にし，これに臭素を付加し，ジメチルアミンでジア ミン（7）とし, 徹底的メチル化で黄色の液体を得た。全 収率 $3 \%$ である。

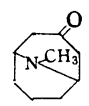

(1)
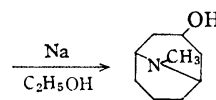

(2)

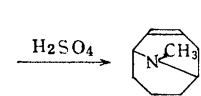

(3)

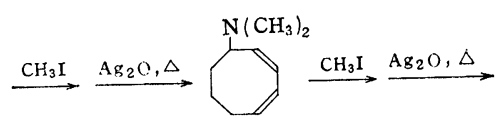

(4)

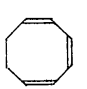

(5)

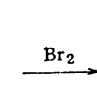

$\mathrm{Br}$

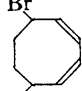

$\mathrm{Br}(6)$
$\mathrm{NH}\left(\mathrm{CH}_{3}\right)_{2}$

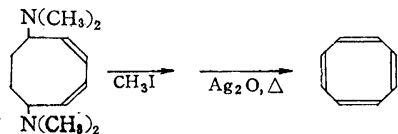

(7)

こうして得られた液体は $\mathrm{C}_{8} \mathrm{H}_{8}$ の組成をもち，水素添 加で 4 モルの水素を吸収することより $1,3,5,7$-シクロ

* 東京大学理学部化学科 (東京都文京区本郷7-3-1)

* Department of Chemistry, Faculty of Science, Tokyo Univ. (3-1, 7-chome, Hongo, Bunkyo-ku, Tokyo)

オクタテトラエンとされた。またその化学的挙動はベン ゼンよりむしろポリオレフィンに近いことが明らかにさ れた。しかしその構造については紫外スペクトルがスチ レンと類似している点や，接触水素添加で Willstätter の化合物がスチレンに変ることより当初より疑問とされ ていだ)。

その後 COT に対して種々の合成が試みられたがいず れも成功しなかった ${ }^{1)}$ 。1940 年 J.W. Reppe はアセチレ ンの重合で，初めて容易に多量の COT の合成に成功し た4)。たとえば，ニッケルシアニドを触媒とし，THF 中， $60 \sim 70^{\circ} \mathrm{C}$ でアセチレンの圧力を 15〜20 気圧に保 つと, 30 60 hr $\operatorname{COT}(70 \%)$, ベンゼン (15\%), その他少量のナフタリン, アズレン, 組成式 $\mathrm{C}_{10} \mathrm{H}_{10}, \mathrm{C}_{12}$ $\mathrm{H}_{12}$ の炭化水素が得られる。こうして合成された COT の物理定数はWillstätter の COT と完全には一致しな かった。これは, Willstätter が少量のCOT しか得られ ず，充分精製できなかったためであろう。1948 年 Cope は Willstätter の実験を追試し，実に 35 年後にその実 験の正しいことを明らかにした5)。

COT の反応については，第二次世界大戦中ドイッの I.G. Farbenindustrie の研究所で Reppe のもとにドイ ツ化学者によって広範囲に研究された。戦後その結果が FIAT, BIOS, PB リポートとして伝えられ，最終的に Liebigs Ann.に発表されるにおよんで，COT の化学が あらためて注目され，以来数多くの研究がなされてき た4,6)。しかし，それにもかかわらず COT の工業上有 用な用途はいまだ見出されていない。一方，その奇妙な 反応性の故に, 理論有機化学の対象として取り上げら れ，シクロオクタテトラエンジアニオンやCOT の二量 体からブルバレンの合成等, 興味ある研究がなされてい る。この総説では最近の研究経過をのべる。

\section{I. シクロオクタテトラエンの構造}

COT は赫線吸収スペクトルより， $1639 \mathrm{~cm}^{-1}$ に非 
共役二重結合の吸収がある7)。また明白な紫外線吸収ピ 一クは認められないが8)，短波長 側に移るにしたがい， 徐々に吸収が増大する。核磁気共鳴吸収をみると, $4.32 \tau$ に一本の吸収があるだけである"。これらの事実はいず れも COT が平面形をしているのではなく，4個の二重 結合間の $\pi$ 電子の共役が小いことを示している。実際, 燃焼熱の測定や，水絜添加熱の 測 定からは，4.8 kcal./ $\mathrm{mol}^{10)}, 2.4 \mathrm{kcal} . / \mathrm{mol}^{11)}$ と小さな共鳴エネルギーが得ら れている。COT の電子線回折の測定，シクロオクタテ トラエニルカルボン酸のX線回折の測定から，COT は $\mathrm{D}_{2 \mathrm{~d}}$ の対称性をもつタブ形をしていて, 単結合, 二重 結合の距離は通常の值, $1.48 \AA, 1.35 \AA$ に非常に近い。

\begin{tabular}{lrc} 
& \multicolumn{1}{c}{$\mathrm{COT}^{12)}$} & $\mathrm{COT}-\mathrm{CO}_{2} \mathrm{H}^{13)}$ \\
$\mathrm{C}=\mathrm{C}$ & $1.334 \pm 0.001 \AA$ & $1.332 \pm 0.005 \AA$ \\
$\mathrm{C}-\mathrm{C}$ & $1.462 \pm 0.001 \AA$ & $1.470 \pm 0.005 \AA$ \\
$\mathrm{C}-\mathrm{H}$ & $1.090 \pm 0.005 \AA$ & \\
$\angle \mathrm{C}=\mathrm{C}-\mathrm{C}$ & $126.46 \pm 0.23^{\circ} \mathrm{C}$ & $126.4 \pm 0.4$
\end{tabular}

$\angle \mathrm{C}=\mathrm{C}-\mathrm{H} \quad 118.3 \pm 5.9 \mathrm{C}^{\circ}$

COT の反転の活性化エネルギーは NMRにより， $\mathrm{C}^{13}$ に着目し，13.7 kcal. $/ \mathrm{mol}\left(-10^{\circ} \mathrm{C}\right.$, 二硫化炭素中) と测 定されている14)。同じように，フルオルシクロオクタテ トラエンの反転に対して $12 \mathrm{kcal} . / \mathrm{mol}\left(-33^{\circ} \mathrm{C}\right)$ の活性 化エネルギーが求められている15)。

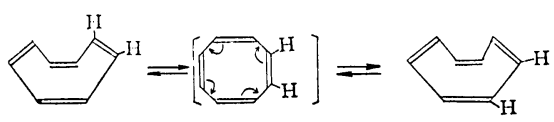

\section{II. シクロオクタテトラエンの合成 および生成反応}

COT はすでにのべたように Willstätter により始め て合成された 2)。その後 Reppe がアセチレンの重合で $\mathrm{COT}$ の合成に成功して以来, 種々のシクロオクタテト ラエン誘導体が㯰換アセチレンの重合，およびアセチレ ンと置換アセチレンの共重合で合成されている。

$$
\begin{aligned}
& \mathrm{HC} \equiv \mathrm{CH}+\mathrm{R}-\mathrm{C} \equiv \mathrm{CH} \frac{\mathrm{Ni}(\mathrm{CN})_{2}, 150 \sim 300 \text { P.S. } \mathrm{i} .}{\mathrm{THF}, 70 \sim 90^{\circ} \mathrm{C}} 10 \sim 20 \% \\
& \mathrm{R}: \mathrm{CH}_{3}, n-\mathrm{C}_{3} \mathrm{H}_{7}, \mathrm{C}_{6} \mathrm{H}_{5}, \quad 16 \text { ) }
\end{aligned}
$$

$\mathrm{HC} \equiv \mathrm{CH}+\mathrm{R}-\mathrm{C} \equiv \mathrm{C}-\mathrm{R} \frac{\mathrm{Ni}(\mathrm{CN})_{2}, 300 \sim 350 \mathrm{P} \cdot \mathrm{S}: \mathrm{i}, ~}{\mathrm{THF}, 70 \sim 90 \mathrm{C}}$ $\mathrm{R}: \mathrm{CH}_{3}, \mathrm{C}_{6} \mathrm{H}_{5}$

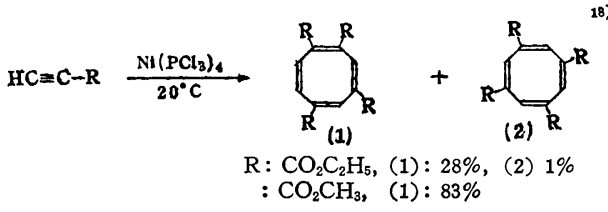

これら Reppe 反応の機 構についてくわしいことは明 らかでないが，現在二通りの機構が呈出されている ${ }^{19) 。 ~}$ 一つはアセチレンが二量化し，まずシクロブタジェンが でき，これの二量化で COT ができる。テトラメチルシ クロブタジェンと塩化ニッケルとのニンプレックスが熱 分解でテトラメチルシクロオクタテトラエンを生成する ことが一つの証拠となっている。

$$
2 \mathrm{HC} \equiv \mathrm{CH} \stackrel{\mathrm{NiX}_{2}}{\longrightarrow}\left[\mathbb{L}^{-} \| \mathrm{NiX}_{2}\right] \rightarrow \longrightarrow
$$

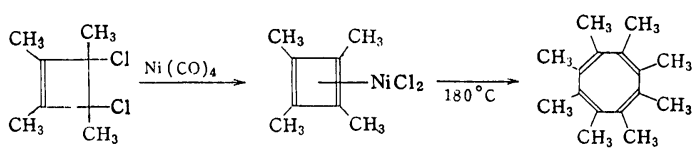

別の機構では 4 個のアセチレンが塩化ニッケルに配位 し安定な 6 配位のコンプレックスを経て COT ができ る。塩化ニッケルに触媒毒として当量のトリフェニルホ スフィンを加えると， ベンゼンのみができる。また $o-$ フェナントロリンを加えると 6 配位座の中の 2 配位座が おさえられ，反応が起らないことから，この機構の方が 妥当とされている。
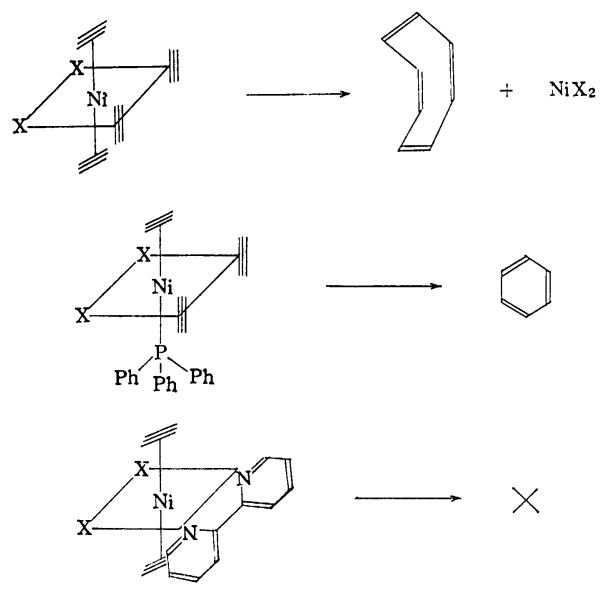

最近 COTを生成するおもしろい反応がかなり多く見 出されている。これらはいずれも次のような段階を含 む。

2

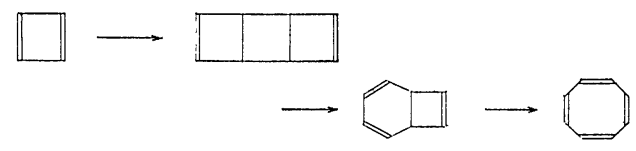

各中間体が捕捉されている場合もあり，いない場合も ある。最近の研究例を列挙する。 


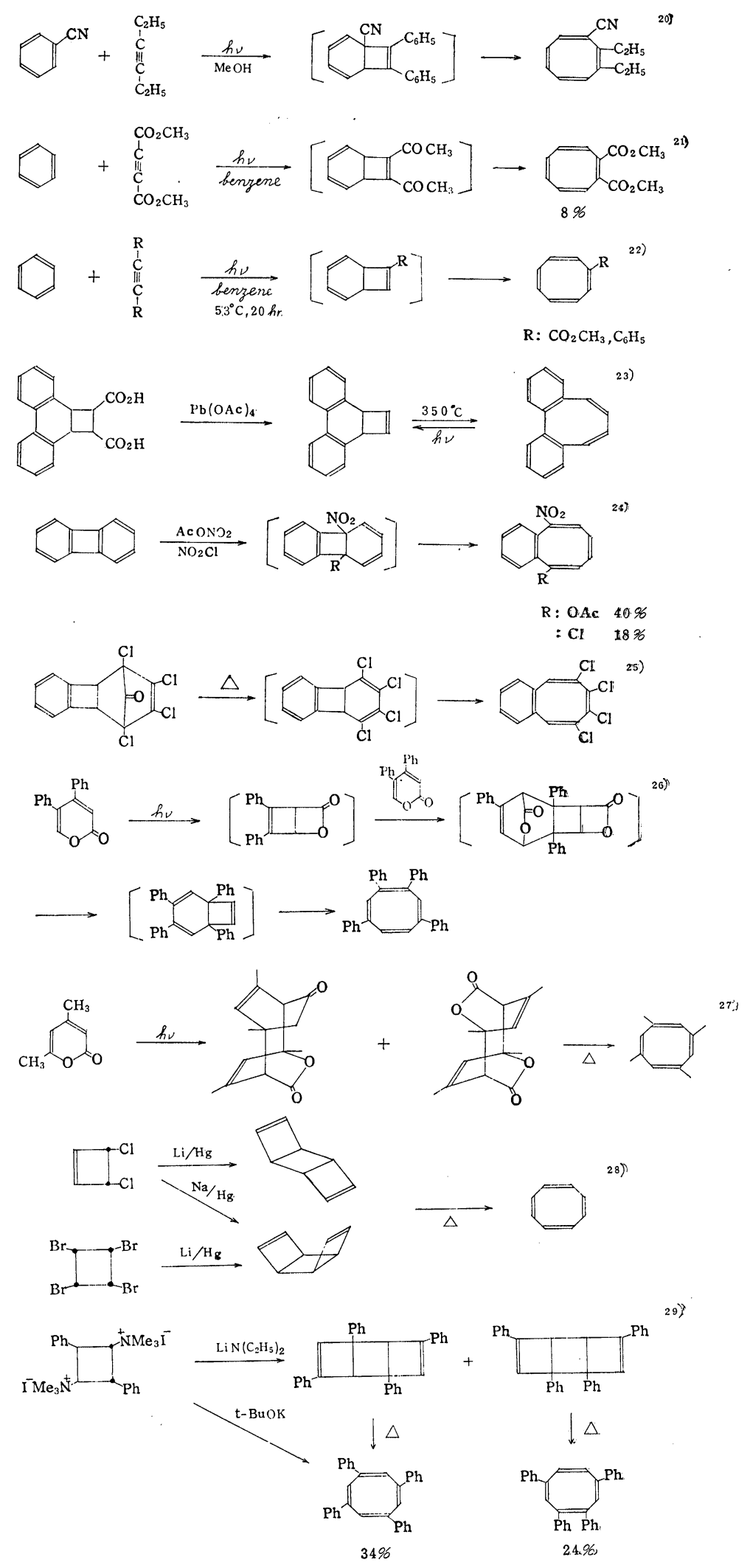




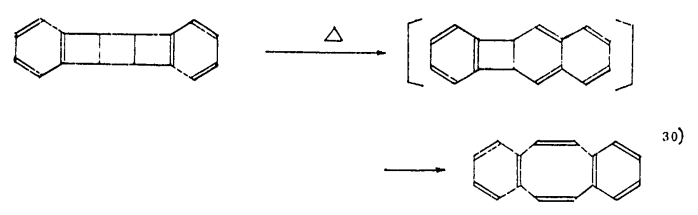

$\| \mathrm{R}+\mathrm{R}_{1}-\mathrm{C} \equiv \mathrm{CH}+\mathrm{R}_{2}-\mathrm{C} \equiv \mathrm{C}-\mathrm{H} \longrightarrow$

$\mathrm{R}_{1}, \mathrm{R}_{2} ; \mathrm{C}_{6} \mathrm{H}_{5}, p-\mathrm{Br} \mathrm{C}_{6} \mathrm{H}_{4}$. etc.
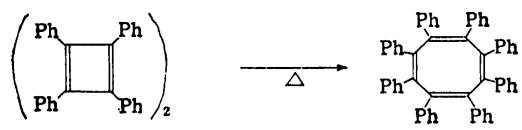

32)

その他バルレンの光照射でも COT ができる。

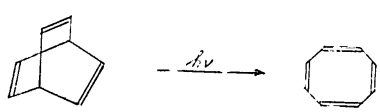

\section{III. 熱転位および光化学反応}

$\mathrm{COT}$ の種々の反応をみると, $\operatorname{COT}(1)$ とビシクロ 【4.2.0〕オクタトリエン-2, 4,7(2) の間に平衡があり,

(2) が反応に関与しているとすると上手に説明される場 合が多い。

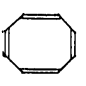

(1)
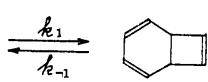

(2)
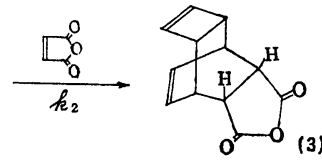

たとえば無水マレイン酸は COT と（3）のような付加物 をつくる*,34)。

Huisgen は $\mathrm{Ph}$-COTと種々のジエノフィルの反応速 度を酶酸エチル中, $70^{\circ} \mathrm{C}$ で測定した ${ }^{36)}$ 。この反応で $k_{2} 》$ $k_{1}$ がなりたてば，全体の反応速度は $k_{1}$ によって決まり， ジエノフィルの濃度によらなくなる。すなわち，(4) か

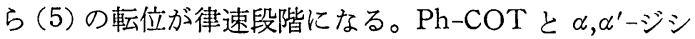
アンマレインイミドの反応はこの条件にあい，その反応 速度の測定より（4）から（5）の転位の活性化エネルギー として $, \Delta \mathrm{H}^{*}, 25 \mathrm{Kcal} . / \mathrm{mol}, \Delta \mathrm{S}^{*}$, 一 $\mathrm{e}$.u. を得た。こ の結果をもとにして，(2) は室温で 0.01\% 存在し, (1) から（2）の転位の活性化エネルギーを $19 \mathrm{kcal} . / \mathrm{mol}$ と推 定した。

* 最近正宗らは(3)より下の反応経路でバスケッテンの合成に成功して
(ねる35)。

(3)

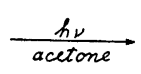

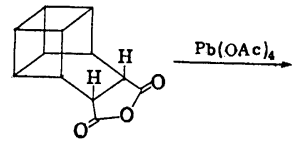

これより以前, Fonken は COT の光分解 (エーテル

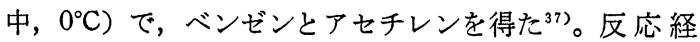
過を UV スペクトルで追跡すると, 反応の途中で $283 \mathrm{~m} \mu$ に吸収極大があらわれ，(2) が生成していると考えた。 反応物をそのまま水素添加し〔4 .2.0]ビシクロオクタン をとらえ，(2) の存在を明らかにした。

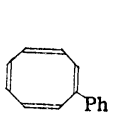

(4)

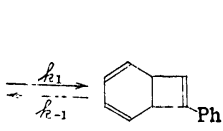

(5)

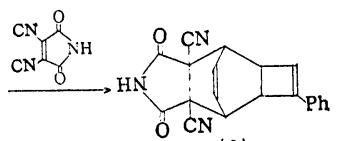

(6)
Vogel は 7,8-ジブロムビシクロ[4.2.0]オクタジエ ン-2, 4(7) にジメチルエーテル中, $-75^{\circ} \mathrm{C}$ でフェナン トレンジアニオンを作用させ, 純度 $95 \%$ の（2）を得 $た^{38)}$ 。(2) は $0^{\circ} \mathrm{C}$ で半減期 14 分で COT になる。

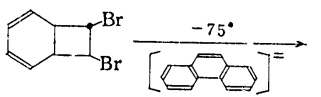

(7)

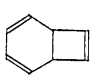

(2)
(1)

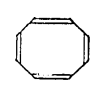

（1）から（2）の転位の活性化エネルギーは $\mathrm{Ea}=18.7$ $\pm 0.8 \mathrm{kcal} / \mathrm{mol}, \mathrm{A}=9.1 \times 10^{11} \mathrm{sec}^{-1}$ 。

1,2, 4, 7-テトテフェニル COT は光でまず熱不安定な 異性体に転位しさらに光で $p$-ターフェニルとトランに 分解する ${ }^{39)}$ 。中間体の構造は不明で, 分光学的データー は予想される構造 (9) では説明できない。これに対し著 者は構造 (10) も検討してみる必要があると思う。<smiles>c1ccc(-c2ccccc2)cc1</smiles>

(7)
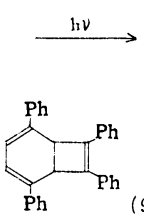

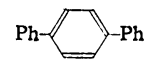

$\div \quad \mathrm{Ph}-\mathrm{C} \equiv \mathrm{C}-\mathrm{Ph}$

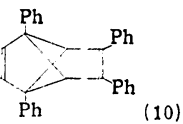

1,2,4,6-テトラカルボエトキシ COT は熱で同じよう に分解し，1,2,4-トリカルボエトキシベンゼンとカルボ エトキシアセチレンになる ${ }^{18)}$ 。

5, 6-二置換ジベンゾシクロオクタテトラエン (11) は デカリン中またはそのまま $140 \sim 200^{\circ} \mathrm{C}$ に熱せられると 高収率で 5,11-異性 体 (12) に転位する ${ }^{31}$ 。(11a) と(11 c）の混合物を異性化して (12a) と（12c）のみが得ら れ，(12d) は得られなかった。また (11d) からは (12d) だけで (12a), (12c) はえられない。したがって反応は (13) のような中間体をとおるのではなく，(14）のよう な中間体をとおる。 


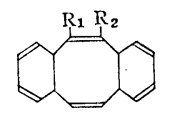

(11)
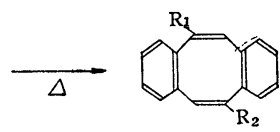

(12)

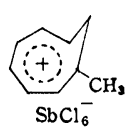

(2)

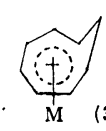

(3) $\mathrm{M}=\mathrm{Mo}(\mathrm{CO})_{3}$

(4) $\mathrm{M}=\mathrm{Fe}_{2}(\mathrm{CO})_{6}$ a $\mathrm{R}_{1}, \mathrm{R}_{2}=\mathrm{C}_{6} \mathrm{H}_{5} \quad$ c $\mathrm{R}_{1}, \mathrm{R}_{2}=p-\mathrm{BrC}_{6} \mathrm{H}_{4}$

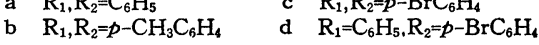

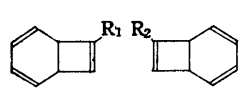

(13)

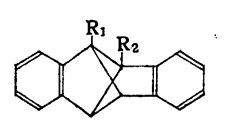

(14)

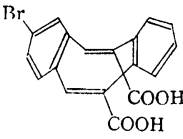

(15)

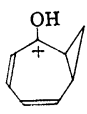

(5)

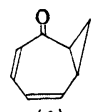

(6) $\begin{array}{ccr} & \Delta \mathrm{H}^{*} . \mathrm{kcal} / \mathrm{mol} & \Delta \mathrm{S}^{*} . \text { e.u. } \\ \text { (11a) } & 28.9 & -13 \\ \text { (11b) } & 29.1 & -12 \\ \text { (11c) } & 31.7 & -7\end{array}$

Mislow は光学活性な $\operatorname{COT}(15),[\alpha]_{\mathrm{D}}^{21}=+71.2^{\circ} \mathrm{C}$, -61.6 ${ }^{\circ} \mathrm{C}$ を合成し, 反転の活性化エネルギーを求め $た^{40)}$ 。 $\mathrm{Ea}=27 \mathrm{kcal} / \mathrm{mol}, \mathrm{A}=10^{11} \mathrm{sec}^{-1}\left(130^{\circ} \mathrm{C}\right.$, エチレン グリコール中）この值は（11）の転位の活性化エネルギ 一に非常に近いことより, 同じ遷移状態を経るものと推 定される。

\section{IV. 酸, 塩基टの反応}

$\mathrm{COT}$ と $\mathrm{Fe}(\mathrm{CO})_{3}, \mathrm{MO}(\mathrm{CO})_{3}, \mathrm{SbCl}_{5}$ 等の金属塩と

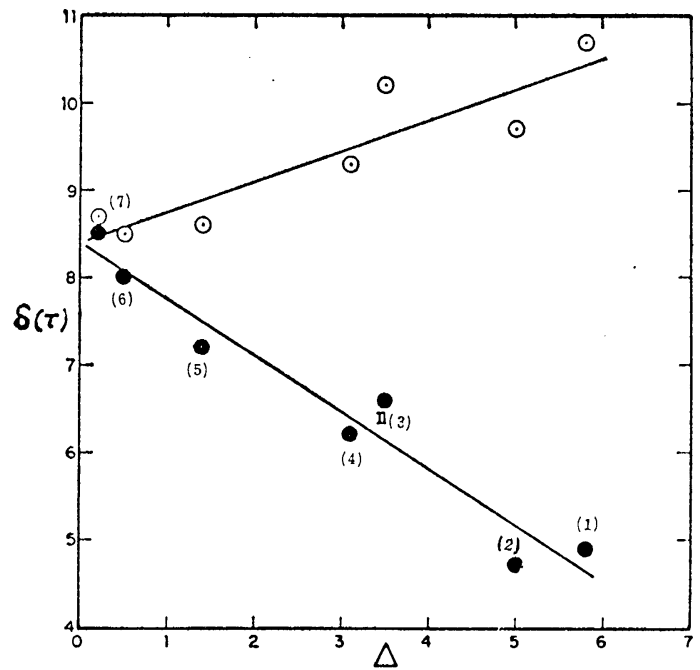

图 1

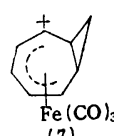

(7)

(1) では $\mathrm{Ha}, \mathrm{Hb}$ の化学シフトの差は $5.8 \mathrm{ppm}$ もり, 明らかに環電流の影響で Ha が強くしゃへいされている ことがわかる。したがってこの塩は非古典的カルボニウ ムイオン構造をしている。ところが (7) では $\mathrm{Ha} \mathrm{Hb} の$ 化学シフトの差は $0.18 \mathrm{ppm}$ と小さく，(7)のような古 典的カルボニウムイオン構造が妥当と思われる。害際 (7) の還元でホモトロピリデン (8) が単離されるが42), (1) $\mathrm{LiAlH}_{4}$ で処理してもビシクロ [5.1.0〕オクタ ンは単離されない。

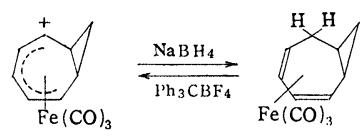

(8)

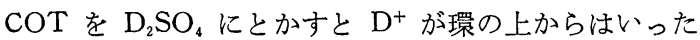
ような形のもの（9a）が主にできる。溶液で放置すると (9a) と (9b) の平衡混合物になる。(9a) から (9b)の 転位速度は, $9.8 \times 10^{-4} \mathrm{sec}^{-1}, 37^{\circ} \mathrm{C}, 6.1 \times 10^{-4} \mathrm{sec}^{-1}$, $32^{\circ} \mathrm{C}, \Delta \mathrm{F}^{*}=23.3 \mathrm{kcal} / \mathrm{mol}^{43}$ )。

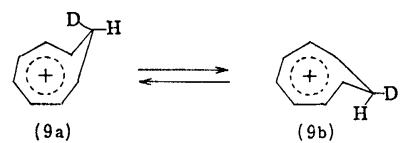

Krebs は Br-COT(10) に $t$-BuOK を作用させ, 中 間体（11）をフェニルアジドやテトラフェニルシクロペ ンタジエノンで捕捉した ${ }^{44}$ 。

のコンプレックスを強酸にとかすとホモトロピ リウム塩ができる。種々の塩 (1)〜 (7) につい て $\mathrm{Ha}, \mathrm{Hb}$ の化学シフトと化学シフトの差を図 示するとよい直線関係がある ${ }^{41}$ （図 1)。<smiles>c1ccccc1</smiles>

$\mathrm{SbCl}_{6}^{-}$

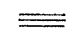

(1)<smiles>C1=C[CH+]C2CCC2C=C1</smiles>

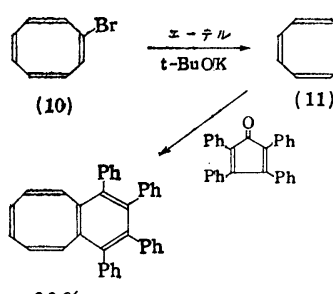

$38 \%$

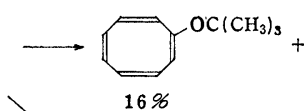

$16 \%$

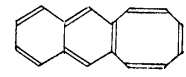

395 


\section{V. ハロゲン化反応}

COTに 1 モルの塩素を付加させると主にシス-7.8-ジ クロルビシクロ [4.2.0) オクタジエン-3,4(1) と少量の

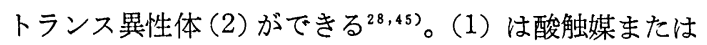
加熱により（2）に転位する。

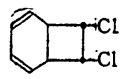

(1)

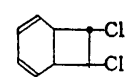

(2)
塩素のかわりに臭素を加えるとトランス異性体のみで き，シス異性体はできない(45,46)。この両者のちがいにつ いて種々議論があった ${ }^{28,46)}$ 。最近 Huisgen はブロム化 の反応を重クロロホルム中, $-55^{\circ} \mathrm{C}$ で行い, 反応物の 温度による変化を NMR で追跡した ${ }^{47}$ 。そその結果低温 では（3)，(4)，の平衡はほとんど（3）にかたよってい て, (3) が臭素と反応する。付加物 (5) は 6 個のオレフィ ンの $\mathrm{H}$ と 2 個の脂肪族の $\mathrm{H}$ をち, オゾン分解 $\left(-55^{\circ} \mathrm{C}\right)$ でメソージブロム酒石酸 (6)-(38\%) になる。したがっ て (5) はシス-7, 8-ジブロム-1, 3, 5-シクロオクタトリエ

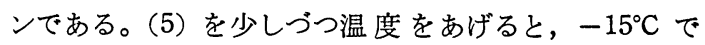

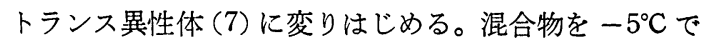
オゾン分解すると (6) の外に $d, l$-ジブロム酒石酸 (8) が単離される。 $0^{\circ} \mathrm{C}$ 以上になると (7) から (9) の転位が おこり，20ㄷ で長時間放置すると完全に (9) に転位す る。転位速度は $+5^{\circ} \mathrm{C}$ で, $k=1.45 \times 10^{-4} \mathrm{sec}^{-1}$ 。

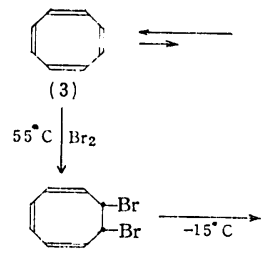

(5)

$-55^{\circ} \mathrm{C} / \mathrm{O}_{3}$

$\mathrm{COOH}$

$\mathrm{H}-\mathrm{C}-\mathrm{Br}$

$\mathrm{H}-\mathrm{C}-\mathrm{Br}$

$\mathrm{COOH}$

(6)

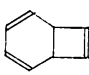

(4)

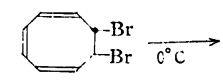

(7)

$-5^{\circ} \mathrm{C} \mid \mathrm{O}_{3}$

$\mathrm{COOH}$

$\mathrm{H}-\mathrm{C}-\mathrm{Br}$

$\mathrm{Br}-\stackrel{1}{\mathrm{C}}-\mathrm{H}$

$\mathrm{COOH}$

\section{VI. カルベンおよびナイトレンとの反応}

COT はカルベンまたはカルベノイドと反応して, ビ シクロ [6.1.0]ノナトリエン-2, 4, 6 誘導体 (1) をあた える。これらは比較的安定であるが加熱すると，いずれ も 8,9-ジヒドロインデン誘導体（2）に転位する。

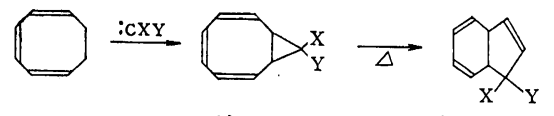

(1)

(2)

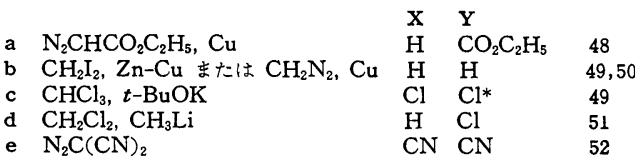

アジドギ酸エチルの光分解で生じるナイトレンも同じ ような生成物，9-アザビシクロ [6.1.0]ノナトリエン

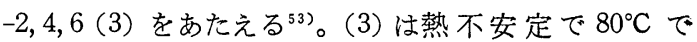
（4）になる。シアノゲンアジドの熱分解で発生するシア ノナイトレンもそれぞれ 1,2-拉よび 1,4-付加物 (5), （4）をあたえる。(5) は一重項，（4）は三重項ナイトレ ンによってできる ${ }^{54)}$ 。

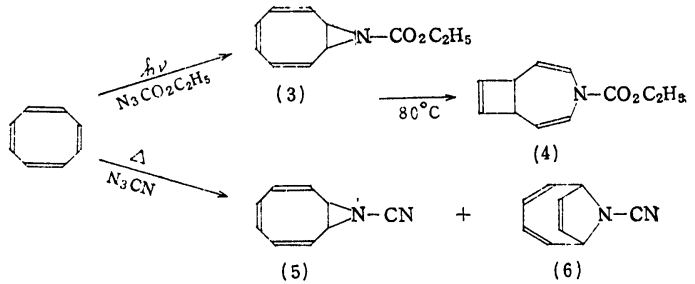

\section{VII. = 量 体}

COT には m.p. $38.5^{\circ} \mathrm{C}(1), 41.5^{\circ} \mathrm{C}(2), 53^{\circ} \mathrm{C}(3)$, $76^{\circ} \mathrm{C}(4)$ の 4 種の二量体が知られている。(1), (2) は COT を 130 $170^{\circ} \mathrm{C}$ に加熱すると得られ, $100^{\circ} \mathrm{C}$ 以下 では (3), (4) が得られる。

(1) は二重結合二個有し，X線で構造が決められた ${ }^{55) 。 ~}$ （2）は水素添加で 3 モルの水素を吸収。紫外スペクトル から三員環に共役する二重結 合 $(232 \mathrm{~m} \mu), \mathrm{NMR}$ スペ

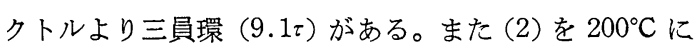
加熱すると (1) に異性化することから (2) の構造が決め, られた ${ }^{56)}$ 。

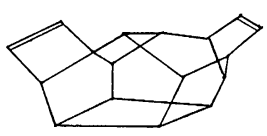

(1)

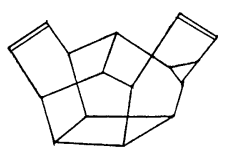

(2) （3）については最初，種々のデーターより（3a）とさ れていたが57), 接触水素添加で 6 モルの水素を吸い, オ ゾン酸化でシクロブタンテトラカルボン酸をあたえるこ とより(3b)とされた ${ }^{58)}$ 。

*転位して 


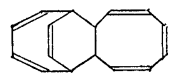

(3a)

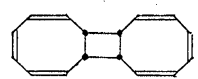

(3b)

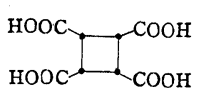

$\mathrm{HOOC} \cdot \mathrm{COOH}$

（4）も最初 (4a) の構造をしているとされたが57)，現 在では NMR による研究で (4b) の構造が妥当とされて いる59)。(4) に光をあてると好収量でベンゼンとブルバ レンが ${ }^{60)}$ ，また次式にしたがいフェニルブルバレンがで きる ${ }^{61)}$ 。

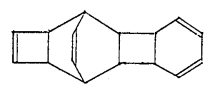

(4a)

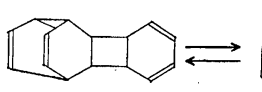

(4b)

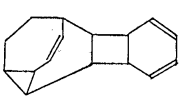

(4)

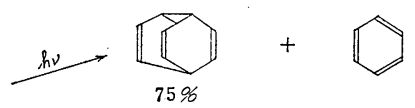

$+{ }^{t-B_{4} O_{K}}$

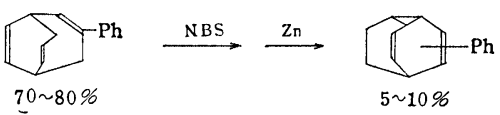

VIII. シクロオクタテトラエンアニオンラジカ ルとシクラオクタテトラエンジアニオン

COT はエーテルまたはアンモニヤ中でナトリウムや カリウム金属で容易に還元され，ジアニオン (1)をつく ることは古くより知られていた。（1）は加水分解でシク ロオクタトリエン (2) に, 二酸化炭素と反応してジカル ボン酸 (3) になる $\left.{ }^{4} .62\right) 。$
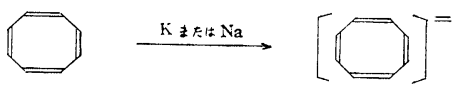

(1)

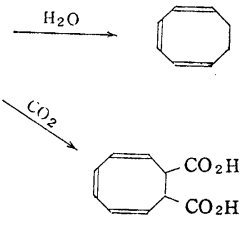

(2)
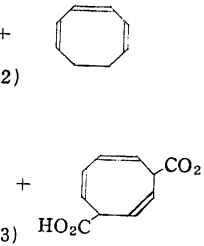

Katz はこのような性質をもつジアニオン (1) が芳香 族性をもつことを NMR や ESR を使って明らかにし た ${ }^{63)}$ 。COT, シクロオクタテトラエンアニオンラジカ ル, $\mathrm{COT}$ テシクロクタテトラエンジアニオン, $\mathrm{COT}=$ の間には次の平衡がある。
$\mathrm{A} \quad \mathrm{COT}+2 \mathrm{e} \leftrightharpoons \mathrm{COT}=$
B $\mathrm{COT}^{=}+\mathrm{COT}=\longleftrightarrow 2 \mathrm{COT}^{\top}$
C COT $^{=}+\operatorname{COT}^{-} \leftrightharpoons \operatorname{coT}^{\top}+\mathrm{COT}^{=}$

テトラヒドロフラン中，またはジメトキシェタン中で
COT 1 モルに 2 モルのアルカリ金属をとかすと, 激し く反応して黄色の結晶 (1) ができる。反応経過を NMR で追跡すると，T.H.F. の低磁場 側 の吸収より 125.35 cps 低磁場にある COT のするどい吸収が少しゔつ減少 し，強度がもとの 1/10 になると巾広い吸収がそれにか さなるようにあらわれる。すなわち，反応がかなりすす んでも COT の吸収が残っていることより, $\mathrm{COT}^{\top}$ の 濃度はうすく，平衡は左によっていることがわかる。さ らに反応が進むと最初のするどい吸収が消え，全体がや や巾の広い小さな吸収になり，平衡Cで電子の交換がか なりはやく起っていることが分る。最後に同じ位置で一 本のするどいジアニオンの吸収に変る。この結果 COT= では電子が一部に局在化しているより全体に散らばって いると考えた方がよい。

いま COT が平面形をしていると仮定した場合，その $\pi$ 電子エネルギー準位は単統 Hückel 分子軌道法で次の ようになる。

$$
\begin{aligned}
& E_{k}=\alpha+2 \beta \cos \frac{2 k \pi}{\mathrm{n}} \\
& \mathrm{n}=8, k=0,1, \cdots \cdots \cdots \cdots \cdots, 7
\end{aligned}
$$

最低エネルギー準位より順に, $\alpha+2 \beta, \alpha+\sqrt{2 \beta}, \alpha+$ $\sqrt{2 \beta}, \alpha, \alpha, \alpha-\sqrt{2 \beta}, \alpha-\sqrt{2 \beta}, \alpha-2 \beta$ 。したがって仮 想的な平面形の COT, および平面形の $\mathrm{COT}^{\top}, \mathrm{COT}=$ の $\pi$ 電子エネルギーはそれぞれ， $8 \alpha+4(\sqrt{2}+1) \beta, 9 \alpha$ $+4(\sqrt{2}+1) \beta, 10 \alpha+4(\sqrt{2}+1) \beta$ である。一方 COT の 4 個の二重結合が共役していないで独立だとすると， $\mathrm{COT}$ および仮想的な $\mathrm{COT} \odot, \mathrm{COT}=$ の $\pi$ 電子エネル ギーはそれぞれ， $8 \alpha+8 \beta, 9 \alpha+7 \beta, 10 \alpha+6 \beta$ となる。し たがって平面形をした $\mathrm{COT}, \mathrm{COT}^{\top}, \mathrm{COT}=$ の非局在 化エネルギーは $-1.7 \beta,-2.7 \beta,-3.7 \beta$ である。COT は電子を 1 個ないし 2 個もらうことによってタブ形を平 面形にするのに十分な安定化エネルギーをうることがわ かる。

Katz, 吉田等はジベンゾシクロオクタテトラエンにつ いて同じような研究を行った ${ }^{64)}$ 。またアルキルシクロオ クタテトラエンについても同じような研究がなされてい る ${ }^{65)}$ 。

$\mathrm{COT}=$ は種々のジェムジ八ロゲン化物と反応して，ビ シクロ〔6.1.0]ノナトリエン誘導体（4）をあたえる51， 66)。

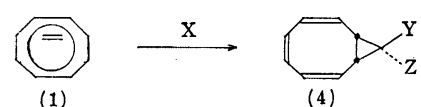




\begin{tabular}{l|l|l|l}
\hline & $\mathbf{X}$ & $\mathbf{Y}$ & $\mathbf{Z}$ \\
\hline $\mathbf{a}$ & $\mathrm{CH}_{2} \mathrm{Cl}_{2}$ & $\mathbf{H}$ & $\mathbf{H}$ \\
$\mathbf{b}$ & $\mathrm{CHCl}_{3}$ & $\mathrm{Cl}$ & $\mathbf{H}$ \\
$\mathbf{c}$ & $\mathrm{CCl}_{4}$ & $\mathrm{Cl}$ & $\mathrm{Cl}$ \\
$\mathbf{d}$ & $\mathrm{CH}_{3} \mathrm{OCHCl}_{2}$ & $\mathrm{OCH}_{3}$ & $\mathbf{H}$ \\
$\mathbf{e}$ & $\mathrm{CH}_{3} \mathrm{CHCl}_{2}$ & $\mathbf{H}$ & $\mathrm{CH}$ \\
\hline
\end{tabular}

（4b）はリチウムと，(4d) はカリウムとそれぞれリチ ウムシクロノナテトラエニド (5a), カリウムシクロ

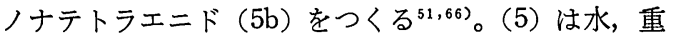
水で 8,9-ジヒドロインデン $(6 \mathrm{a}),(6 \mathrm{~b})$ に, また二酸 化炭素やヨウ化メチルで 1-カルボキシ-8, 9-ジヒドロ インデン (7), 1-メチル-8,9-ジヒドロインデン (8) をあたえる66)。

シクロノナテトラエニルアニオンは $10 \pi$ 電子をも ち, NMR スペクトルは $2.96 \tau$ に一本の鋭い吸収が あるだけで， $\mathrm{COT}=$ と同じように芳香族性をもつ。
$\mathrm{COT}=$ は塩化アセチルと 1,2-付加物 (9), (10), 1,4-付 加物 (11), (12) をつくる ${ }^{67) 。 ~}$

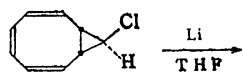

(4b)

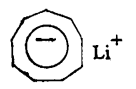

(5a)

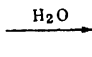

$P^{D_{20}}$

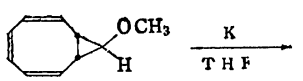

(4d)

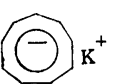

(5b)

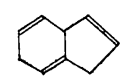

(6a)

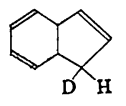

(6b)

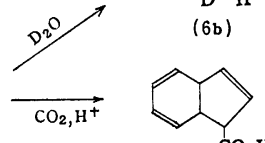

(7) $\mathrm{CO}_{2} \mathrm{H}$

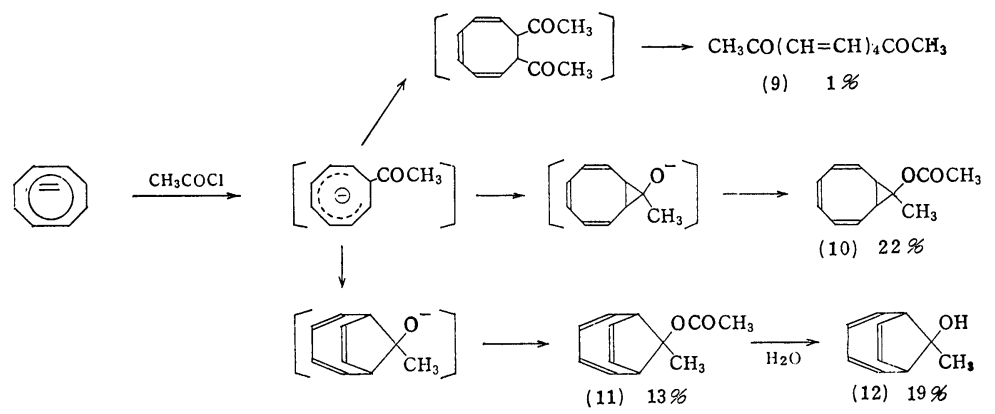

その他，アルデヒドやケトンと以下のように反応する ${ }^{68) 。}$

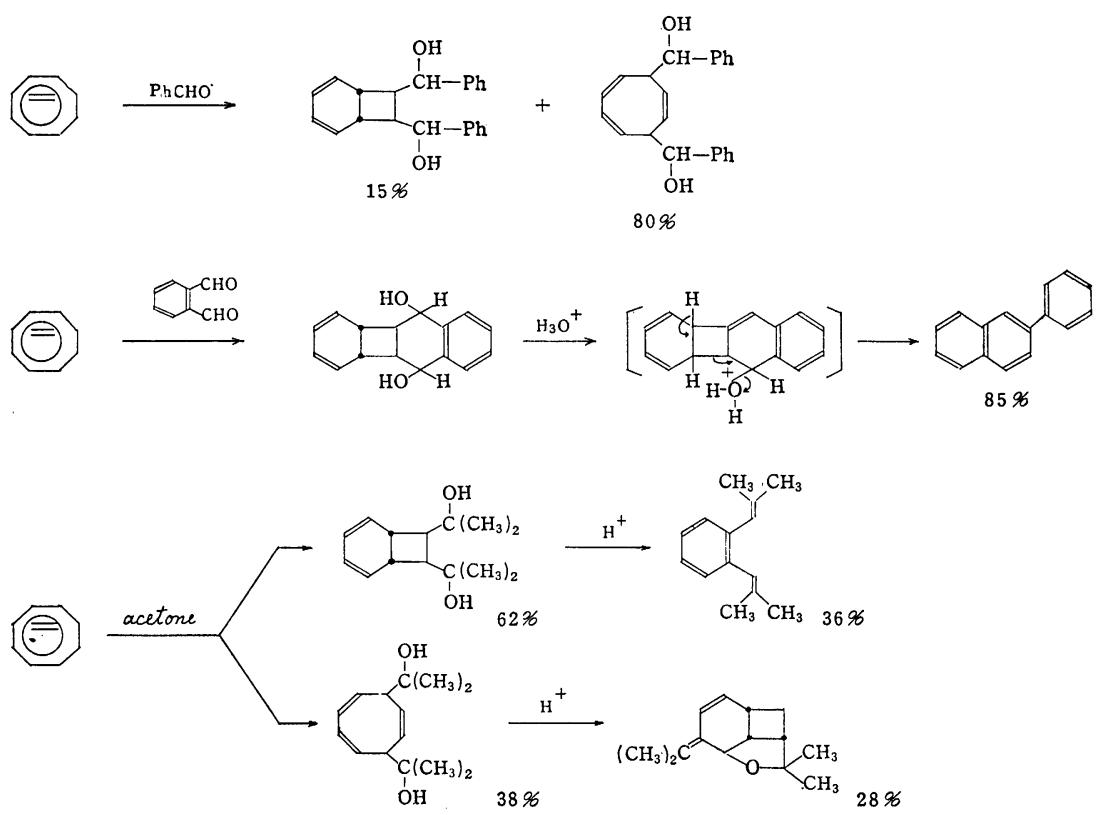




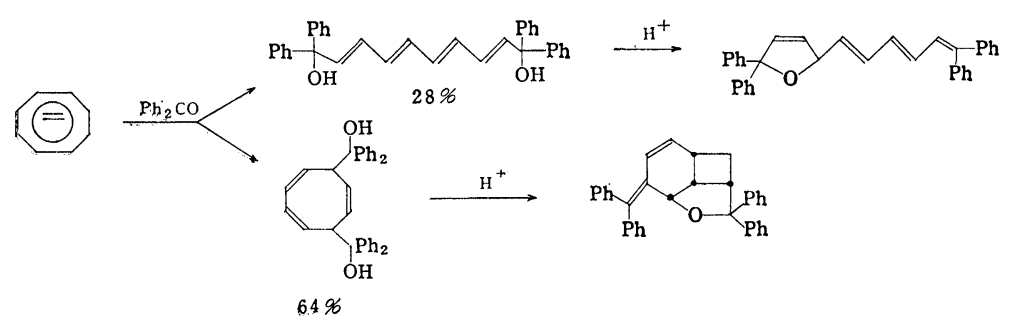

て，2,3-シクロオクタラ゙トラエ ノ-4-メチルシクロペンタジエ ノン(2)を得た。このものは不 安定で単離できない。また（1） をシリカゲルの上に通すと，主 に（2）の異性体（3）と少量の (2) の混合物がとれる。(3) は (2) とちがって安定で蒸留 (105
$\mathrm{COT}=$ とトロピリウムブロミドの反応で $7,7^{\prime}$-ジトロ ピルができる。すなわち COT= は強力な還元作用をも $\supset^{699}$ 。

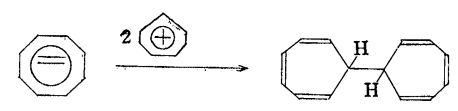

IX. シクロオクタテトラエンジカチオン

シクロオクタテトラエンジカチオンは 6 個の $\pi$ 電子を もち, 芳香族性をもつことが予想される。COT ${ }^{+2}$ が平 面構造をもつとすると, その $\pi$ 電子エネルギーは, $6 \alpha+$ $4(\sqrt{2}+1) \beta$ で, $-3.7 \beta$ と $\mathrm{COT}=$ 同程度の共鳴エネ ルギーをもつことが予想される。現在まだこの COT ${ }^{+2}$ は知られていない: Proctor はトロポンやトロポロンの 類似より (1), (2)を，またアズレンとの類似から (3)の 合成を試みたがいずれも成功していない70)。

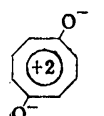

(1)

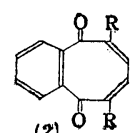

(2)

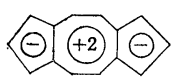

(3) a, $\mathrm{R}=\mathrm{H}$

b. $\mathrm{R}=\mathrm{OH}$
ジフェン酸とヒドロキノンから (4) の合成が試みられた が，フルオレノン誘導体 (5) を得たのにとどまってい る。<smiles>O=C(O)c1ccccc1-c1ccccc1C(=O)O</smiles>

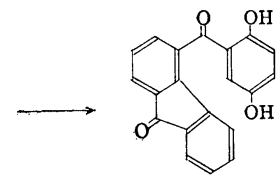

(5)

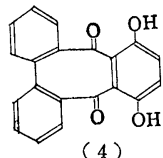

(4)

\section{X. シクロオクタテトラエノシクロペン タジエノン}

Breslow は 2,3-シクロオクタテトラエノ-4-メチル -4'-クロルシクロペンテノン (1) そアルミナの上に通し
${ }^{\circ} \mathrm{C} / 15 \mathrm{~mm}$ ) で精製される。

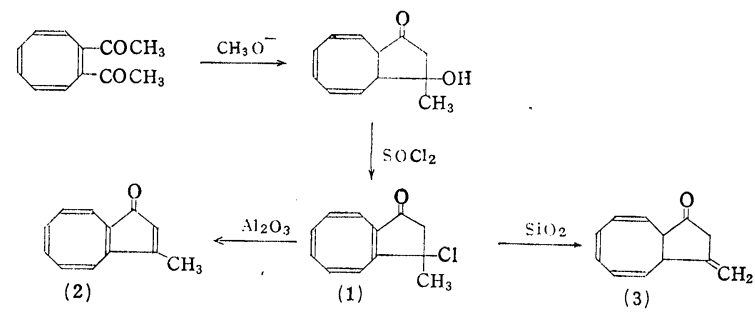

あ亡がき

以上最近の研究例を主に紹介した。このほかにも酸化 や還元反応等紹介せねばならないものも多数あるが，紙 面の都合で省略した。この短い一文が今後この方面の進 歩の一助となれば幸である。

\section{(昭和 41 年 8 月 11 日受理) \\ 文 献}

1) L.E. Craig, Chem. Reviews 49103 (1951); R. A. Raphael, Non-Benzenoid Aromatic Compounds p. 465, Interscience Publishers, Inc., N. Y. (1959)

2) R. Willstätter, E. Waser, Ber. 443423 (1911); R. Willstätter, M. Heidelberger, ibid. 411480 (1913)

3) J.R. Vincent, A.F. Thompson, L.I. Smith, J. Org. Chem. 3603 (1939); W. Baker, J. Chem. Soc. 1945258 ; S. Goldwassen, H.S. Taylor, J. Am. Chem. Soc, 611260 (1939)

4) W. Reppe, O. Schlichting, K. Klager, T. Toepel, Ann. 5601 (1948)

5) A.C. Cope, C.G. Overberger, J. Am. Chem. Soc. 701433 (1948)

6) W. Reppe, O. Schlichting, H. Meister, Ann. 56093 (1948)

7) A.P.I. Project 44 Infrared Spectrogram, 739

8) A.P.I. Project 44 Ultaviolet Absorption Spectrograms, 180, 207

9) J.S. Waugh, R.W. Fessenden, J. Am. Chem. Soc. 79846 (1957)

10) H.D. Springall, T.R. White, R.C. Cass, Tras. Faraday Soc, 50815 (1954)

11) R.B. Turner, W.R. Meador, W. von E. Doering, L.H. Knox, J.R. Mayer, D.W. Wiley, J. 
Am. Chem. Soc. 794127 (1957)

12) O. Bastiansen, L. Hedbery, J. Chem. Phys. 271311 (1957)

13) D.P. Shoemaker, H. Kinder, W.G. Sly, R.C. Srivastava, J. Am. Chem. Soc. 87482 (1965)

14) F.A.C. Anet, J. Am. Chem. Soc. 84671 (1962)

15) D.E. Gwynn, G.M. Whitesides, J.D. Roberts, J. Am. Chem. Soc. 872862 (1965)

16) A.C. Cope, H. Cambell, J. Am. Chem. Soc. 74179 (1952); A.C. Cope, D.F. Rugen, ibid. 753215 (1953); A.C. Cope, R.M. Pike, ibid. 753220 (1953)

17) A.C. Cope, D.S. Smith, J. Am. Chem. Soc. 745136 (1952)

18) J.R. Leto, M.F. Leto, J. Am. Chem. Soc. 83 2944 (1961)

19) G.N. Schrauzer, P. Glockner, S. Eicher, Angew. Chem. 7628 (1964)

20) J.G. Atkinson, D.E. Ayer, G. Büchi, W. Robb, J. Am. Chem. Soc. 852257 (1963)

21) E. Grovenstein, Jr., D.V. Rao, Tetrahedron Letters. 1961148

22) D. Bryce-Smith, J.E. Lodge, J. Chem. Soc. 695 (1963)

23) E. Vogel, W. Frass, J. Wolpers, Angew. Chem. 75979 (1963)

24) J.W. Barton, K.E. Whitaker, Chem. Comm. 516 (1965)

25) A.J. Boulton, J.F.W. McOmie, J. Chem. Soc. 2549 (1965)

26) A.Padwa, R. Hartman, J. Am. Chem. Soc. 86 4212 (1964)

27) P. de Mayo, R.W. Yip, Proc. Chem. Soc. 84 (1964)

28) M. Avram, I.G. Dinulescu, E. Marica, G. Mateescu E. Sliam, C.D. Nenitzescu, Ber. 97 372 (1964)

29) E.H. White, H.C. Dunathan, J. Am. Chem. Soc. 86453 (1964)

30) M.P. Cava, R. Pohlle, J. Org. Chem. 281012 (1963)

31) M. Stiles U. Burckhardt, J. Am. Chem. Soc. 863396 (1964)

32) R.A. Saunders et al., J. Chem. Soc. 7052 (1965)

33) H.E. Zimmerman, G.L. Grunewald, J. Am. Chem. Soc. 88183 (1966)

34) M. Avr. M. G. Mateescu, C.D. Nenitzescu,Ann. 636174 (1960); R.C. Cookson, J. Hudec, J. Mardsen, Chem. \& Ind. 21 (1961)

35) S. Masamune, H. Cuts, M.G. Hogben, Tetrahedron Letters, 1017 (1966)

36) R. Huisgen, F. Mietzch, Angero. Chem. 7636 (1964)

37) G.J. Fonken, Chem. \& Ind. 1625 (1963)

38) E. Vogel, H. Kiefer, W.R. Roth, Angew. Chem. 76432 (1964)
39) E.H. White, R.L. Stern, Tetrahedron Letters, 193 (1964)

40) K. Mislow, H.D. Perlmutter, J. Am. Chem. Soc. 843591 (1962)

41) C.E. Keller. R. Pettit, J. Am. Chem. Soc. 88 604,606 (1966)

42) A. Davison, W. McFarlane, L. Pratt, G. Willkinson, Chem. \& Ind. 553 (1961); J. Chem. Soc. 4821 (1962)

43) S. Winstein, C.G. Kreiter, J.I. Brauman, J. Am. Chem. Soc. 882047 (1966)

44) A. Krebs, Angew. Chem. 77966 (1965)

45) V. Georgian, I. Georgian, A.V. Robertson, Tetrahedron 191219 (1963)

46) A.T. Blomguist, A.G. Cook, Chem. \& Ind. 873 (1960) ; N.L. Allinger, M.A. Miller, L.A. Tushans, J. Org. Chem. 282555 (1963)

47) R. Huisgln, G. Boche, Tetrahedron Letters. 1769 (1965)

48) S.A kiyoshi, T. Matsuda, J. Am. Chem. Soc. 772476 (1955) ; D.D. Phillips, ibid. 775179 (1955)

49) E. Vogel, Angerv. Chem. 74838 (1962)

50) E. Vogel, W. Wiedemann, H. Kiefer, W.F. Harrison, Tetrahedron Letters, 673 (1963)

51) E.A. Laucette, R.E. Benson, J. Am. Chem. Soc. 852853 (1963); T.J. Katz, P.J. Garratt, ibid. 864876 (1964)

52) E. Ciganeck, J. Am. Chem. Soc. 881779 (1966)

53) S. Masamune, N.T. Castellucci, Anger. Chem. 76569 (1964)

54) A.G. Anastassion, J. Am. Chem. Soc. 875512 (1965)

55) S.C. Nyburg, I. Hilton, Acta, Crystallogr. 12 116 (1959)

56) H.W. Moore, J. Am. Chem. Soc. 863398. (1964)

57) W.O. Jones, Chem. \& Ind. 16 (1955)

58) G. Schröder, W. Martin, Angew. Chem. 78 117 (1966)

59) G. Schröder, Ber, 973131 (1964); R. Merényi, J.F.M. Oth, G. Schröder, ibid. 973150. (1964)

60) G. Schröder, Ber. 973140 (1964)

61) G. Schröder, Angew. Chem. 77682 (1965)

62) A.C. Cope, F.A. Hochstein, J. Am. Chem. Soc. 722515 (1950); W.R. Roth, Ann. 67125 (1964)

63) T.J. Katz, J. Am. Chem. Soc. 823785 (1960); T.J. Katz, W.H. Reimuth, D.E. Smith, ibid. 84802 (1962) ; H.L. Strauss, T.J. Katz, G.K. Fraenkel, ibid. 852360 (1963)

64) T.J. Katz, M. Yoshida, E. Siew, J. Am, Chem. Soc. 874516 (1965)

65) A. Carrington, P.F. Todd, Mol, Phys. 8299 , (1964) 
66) T.J. Katz, P.J. Garratt, J. Am. Chem. Soc. 86 5194 (1964)

67) T.S. Cantrell, H. Shechter, J. Am. Chem. Soc. 853300 (1963)

68) T.S. Cantrell, H. Shechter, J. Am. Chem. Soc. 87136 (1965)
69) R.W. Murray, M.L. Kaplan, J. Org. Chem. 31962 (1966)

70) D. Mcentyre, G.R. Proctor, Mrs. L. Rees, J. Chem. Soc. 985 (1966)

71) R. Breslow, W. Vitale, K. Wendel, Tetrahedron Letters, 365 (1965)

\section{見 学 記 事}

11月も押迫った30日，第38回見学会としてブリヂスト ンタイヤ (株) 東京工場を訪問した。会誌発行の㧍くれ から申し込みにゆとりがなく，参会者は10数名に過ぎな かったが，霧雨もよいの中をゆっくり落ちついて見学す ることができた。

同工場は中央線国分寺駅加西武国分寺線 3 目の小 川駅の前に広がる 60 万 $\mathrm{m}^{2}$ の広大な土地に所在し，年間 550 万本の生産能力を有するタイヤ工場のほか，技術セ ンター， 25 万 $\mathrm{m}^{2}$ に及ぶ従業員アパート，院病，厚生会 館，スポーツグランド，マーケットなどの厚生施設敷地 を含み，さながら独立したブリヂストン王国を成してい る。そして同社は久留米工場，那須工場を合せて年間 1500万本のタイヤを生産しており，わが国タイヤ市場の 50\%を占めている。

東京工場施設の特徴は同社のみが有するタイヤコード 製織工場があり，すだれ状の長尺コードが，次のデイッ ピングとHT処理を受けて高熱高張力で伸びを固定し， カレンダーロールでコードの両面にゴムをすり込み，バ イヤスカッターで截断し，接着をよくするためスキージ 一ゴムをはり合わせる。一方バンバリーミキサーで原料 ゴム,カーボンブラック，イオウ，加硫促進剤などをま
ぜて配合ゴム練りを行ない，シート状にして熱入れ後ト レッド状に押出し，1本分に截断して，タイヤの骨格を 形成する銅線ビードにゴムをコーティングしたものと合 せてタイヤ張付けを終わる。

この生タイヤはバゴマチックプレスで自動的に加硫さ れるが，この加硫機が当工場には 250 台並んでいて，そ の数は世界最大とのことである。大型タイヤは別室で作 られているが，その $80 \%$ は輸出されているとのことであ る。

従業員 3200 名中通勤者が 1000 名で残りは敷地内の社 宅から出勤している。技術センターは約 500 名中半数が 学卒で, 基碳研究, 新製品開発, 各種材料試験, タイヤ 設計, 工務施設の 5 部から成っており, 円形のスキッド パット式スリップ実車試験場やドラム式台上試験場も完 備されており，敷地のはずれには合成ゴムのパイロット プラントもあるとのことであったが，これらは社外秘で 見学を許されなかった。

いずれにせよ音も煙も悪狊もない工場公園, そしてこ のようなおそらく地価の安、所に位置し得る工場はわれ われ化学関係者にとってうらやましい限りである。

(平川 芳彦) 